\title{
Prospects revive for Japanese magnetically levitated train
}

\section{Tokyo}

THE advent of high-temperature superconductors has revived interest in Japan in magnetically levitated (Maglev) trains at a time when it may be financially feasible to establish commercial lines.

A few years ago, the propects for Maglev trains in Japan looked grim. Although a small unmanned vehicle developed by Japan National Railways (JNR) attained a world record speed of $517 \mathrm{~km}$ per hour on a $7-\mathrm{km}$ test track in the southern island of Kyushu in 1979, funds for development dried up in the early 1980 s as the national railway sank further into chronic debt.

But events over the past year have suddenly made prospects for Maglev much brighter. The break-up and privatization of the national railways freed the newly formed regional Japan Railways (JR) of some of their massive debts, and JNR's laboratories were reborn as a research institute backed by a foundation.

At the same time, the breakthroughs in the development of high-temperature superconductors suddenly made 'superconductor' a household word. And the eyes of politicians and the public turned to the experimental track in Kyushu where a 44-seat prototype vehicle is undergoing tests at speeds up to $400 \mathrm{~km}$ per hour. The fact that JR's Maglev uses conventional niobium-titanium superconductors and that practical wires composed of the new high $T_{c}$ superconductors are probably decades away (if they are ever developed) has not damped the renewed interest.

$$
\text { Also, the privatization of Nippon }
$$

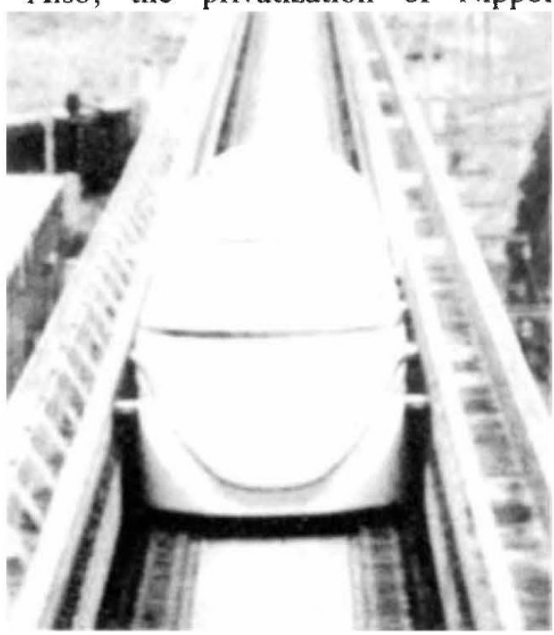

Telegraph and Telephone (NTT) and last year's boom on the Tokyo stock market have brought unexpected millions of millions of yen to the government.

Yet another factor now working in favour of Maglev is foreign competition. Transport Minister Shintaro Ishihara has

\section{Maglev train system for United States?}

\section{Washington}

How best to take advantage of the new high-temperature superconductors has been a frequent theme in the US Congress in the past year. Now, Senator Daniel P. Moynihan (Democrat, New York) thinks that he has found a way. Moynihan has introduced legislation to establish a national transportation system of magnetic levitation (Maglev) trains, based upon superconducting magnets. The trains would reach speeds of between 200 and $\mathbf{3 0 0}$ miles per hour, cutting the travel time from Washington, DC to New York City to one hour.

Congress has been worried that the economic fruits of high-temperature superconductivity research may go to other countries despite increased research spending. Exciting results from other countries - notably West Germany and Japan - has convinced many that Congress must help to find ways to exploit the technology and to establish US supremacy in superconductor research. Japan has already completed a prototype Maglev system, with recorded speeds of $400 \mathrm{~km}$ per hour (see Nature 325, 566; 1987), and Moynihan warns in his legislation that "If we fail to act now . . . [the project] will be based upon imported foreign technology, either Japanese or German".

Moynihan's bill - the Federal Advanced Superconducting Transportation Act, or FAST Act - would kill two birds with one stone: it puts the new developments in superconducting ceramics to use, and at the same time helps to relieve the nation's air traffic congestion problem. The bill would give NASA (National Aeronautics and Space Administration) $\$ 100$ million for research in superconductivity and magnetic levitation over the next three years. It would also establish a High-Speed Ground Transportation Office in the Department of Transportation to oversee the two-year development of the Maglev train system.

Moynihan hopes the system will be under construction within five years after the bill is passed. But critics wonder at his choice of NASA for completing the basic research in superconductivity. The Department of Energy's national laboratories have been leading in the area, and NASA has problems of its own. The current climate of budget belt-tightening also decreases the likelihood of the bill's passage. just returned from West Germany where he inspected the Transrapid train, a competing magnetically levitated train that uses conventional magnets. There are well-grounded fears here that Transrapid may break into the potentially lucrative US market ahead of Japan. For example, Las Vegas wants to build a $370-\mathrm{km}$ line to Los Angeles to bring in more tourists, and officials from Transrapid say they can meet the city's target for completion in 1995. But Japan has yet to build a test track with curves on it.

Ishihara believes that Japan's Maglev can match Transrapid technologically, but Maglev will not impress the world as long as it is confined to runs "between pig pens and chicken coops" in Kyushu. His ministry has won $¥ 780$ million (\$6 million) in fiscal year 1988 (starting in April) to develop Maglev further and $¥ 180$ million has been assigned to a feasibility study for a track several tens of kilometres in length that could be put to commercial use once tests are completed. Two sites for the test track are under consideration - from Chitose airport to Sapporo, the capital of the northern island of Hokkaido, and from Tokyo to Kofu, the capital of Yamanashi Prefecture west of Tokyo.

The Maglev train floats on superconducting magnets that induce a repulsive magnet field in aluminium coils set in the floor of the ' $U$ '-shaped trackway while the train is propelled forward by electromagnets in the trackway walls. The train offers a smooth bump-free ride and can climb steeper inclines than a conventional bullet train. Proponents also say that the costs of constructing and maintaining the trackway are less than for an ordinary Shinkansen. But the Maglev train itself costs 4 to 5 times as much as a bullet train.

Prime Minister Noboru Takeshita and many members of the ruling Liberal Democratic party see high-speed trains as a means to de-centralize Tokyo. They also no doubt see it as a way to ensure reelection - it is said that if a politician can have a Shinkansen station placed in his constituency, he is guaranteed a seat in the Diet for life. But resistance from the Ministry of Finance is strong. In December, a ministry official condemned calls for more Shinkansen lines as "one of the three most foolish plans" of this century - the others being the building of the battleship Yamato and the construction of the Seikan tunnel between mainland Honshu and Hokkaido. The ministry fears that further expenditures on Shinkansen lines will ruin attempts to bring the former national railway out of debt (much of the debt was accrued through the building of Shinkansen lines). And a Maglev line that shortcircuits the present bullet train system would only make matters worse. A decision on future Shinkansen lines has been deferred until this summer.

David Swinbanks 